доктор економічних наук, доцент,

Київський національний університет культури і мистецттв,

Київ, Украӥна,

karasyova.natasha@gmail.com

\title{
КРЕАТИВНІ ІНДУСТРІЇ ЯК ЕЛЕМЕНТ СТРАТЕГІЇ ПОСТІНДУСТРІАЛЬНОГО РОЗВИТКУ
}

Не дивлячись на значний творчий та інтелектуальний потенціал нації розвиток креативних індустрій в Україні відбувається дуже повільними темпами, що негативно впливає на соціально-економічне зростання в цілому. Метою статті $\epsilon$ дослідження особливостей формування та перспектив розвитку креативних індустрій в країні. Було визначено економічний зміст як процес створення, виробництва та комерціалізації креативного контенту; складові, зокрема функціональну творчість, культурну спадщина, ЗМІ та мистецтво; особливості розвитку та динаміку товарообігу міжнародної торгівлі товарами креативної економіки в світі.

Досліджено потенціал таких креативних галузей як IT-технології, медіа, архітектурний дизайн, «хендмейд» та ін. в Україні, визначено приблизну ємність відповідних ринків та перспективи їх зростання. Здійснено аналіз таких проблемних питань, що стосуються відсутності статистичної інформації, кадрового та інфраструктурного забезпечення, фінансового стимулювання креативних індустрій. У результаті було сформовано стратегічні напрями культурної та економічної політики щодо підтримки розвитку креативних сфер.

Ключові слова: креативні індустрії, постіндустріальна економіка, культурна політика, творчий потенціал.

Karasova Nataliia, Doctor of Sciences (Economics), Associate Professor, Kyiv National University of Culture and Arts, Kyiv, Ukraine

\section{Creative industries as a strategy element of the post-industrial development}

Despite the considerable creative and intellectual potential of the nation, the development of creative industries in Ukraine gains pace slowly, which adversely affects national and economic growth in total. The purpose of the article lies in the research of formation peculiarities and the prospects of creative industries development in the country. The article defined economic substance, process of creation, production and commercialization of creative content; such components as: functional creativity, cultural 


\section{КРЕАТИВНІ ІНДУСТРІЇ ЯК ЕЛЕМЕНТ СТРАТЕГІЇ ПОСТІНДУСТРІАЛЬНОГО РОЗВИТКУ}

heritage, mass media and art; features of development and dynamics of international trade goods turnover by goods of creative economics in the world.

The article researched the potential of such creative fields as: IT technologies, media, architectural design, handmade and others in Ukraine, as well as the approximate capacity of correspondent markets and prospects of their development were specified. A series of topical issues were analyzed related to statistics information deficiency, staff and infrastructure assistance, financial encouragement of creative industries. As a consequence, the strategic cultural and economic approach was elaborated to back up the growth of creative fields.

Key words: creative industries, post-industrial economy, cultural policy, creative potential.

Карасева Наталия Анатольевна, доктор экономических наук, дочент, Киевский национальный университет культурь и искусств, Киев, Украина

\section{Креативные индустрии как элемент стратегии постиндустриального развития}

Несмотря на значительный творческий и интеллектуальный потенциал нации развитие креативных индустрий в Украине происходит очень медленными темпами, что негативно влияет на социально-экономический рост в целом. Целью статьи было исследование особенностей формирования и перспектив развития креативных индустрий в стране. Было определено экономическое содержание как процесс создания, производства и коммерциализации креативного контента; составляющие, а именно: функциональное творчество, культурное наследие, СМИ и искусство; особенности развития и динамика товарооборота международной торговли товарами креативной экономики в мире.

Исследован потенциал таких креативных отраслей как ИТ-технологии, медиа, архитектурный дизайн, «хендмейд» и др. в Украине, определена приблизительная емкость соответствующих рынков и перспективы их роста. Осуществлен анализ ряда проблемных вопросов, касающихся отсутствия статистической информации, кадрового и инфраструктурного обеспечения, финансового стимулирования креативных индустрий. В результате были сформированы стратегические направления культурной и экономической политики относительно поддержки развития креативных сфер.

Ключевые слова: креативная экономика, постиндустриальная экономика, культурная политика, творческий потенциал.

Постановка проблеми. Протягом останнього десятиліття креативні (культурні) індустрії є рушійним фактором економічного зростання. Їх формування та розвиток успішно інтегруються в якості основних завдань в економічні стратегії постіндустріальних країн, а великий економічний потенціал визнається такими 
організаціями як Рада Європи, ЮНКТАД, Світовий банк, ОЕСР та ін. Значну увагу розвитку креативної економіки приділяють в ЄС. Програма Європейської комісії «Креативна Свропа» на період 2014-рр. передбачає виділення 1,46 млрд (2019 annual work programme..., 2018) євро на підвищення конкурентоспроможності креативних галузей.

Україна володіє потужим творчим та інтелектуальним ресурсом - головною умовою розвитку креативного сектору економіки. Однак, через відсутність стратегічного бачення та системних перетворень у соціальній і гуманітарній сферах розвиток креативних індустрій в нашій країні відбувається дуже стриманими темпами. У результаті уповільнюється транснаціональна мобільність культурних і творчих робіт, а в національному господарстві утворюється пласт невикористаних можливостей соціально-економічного зростання.

Аналіз останніх досліджень і публікацій. Сучасними адептами креативної економіки є Дж. Хокінс (Howkins, 2001) і Р. Флорида (Florida, 2002), які у світових масштабах досліджували розвиток креативних галузей та їх вплив на соціальноекономічні трансформації в містах, регіонах і країнах. Дж. Джейкобс (Jacobs, 1984), Е. Глейзер (Glaeser, 1998),Ч. Лендрі (Landry, 1995) вивчали детермінанти і концепції креативних міст. Багато вчених фокусувалися на окремих аспектах формування $\mathrm{i}$ функціонування галузі креативної економіки, зокрема, Дж. Порфіріо, Т. Каріло, Л. Моніко (Porfírio, 2018) досліджували розвиток підприємництва в культурномистецьких та науково-технічних сферах творчих індустрій. П. Колінз і Дж. Канінгхем (Collins, Carrilho, Mónico, 2017) вивчали можливості імплементації креативних бізнес-моделей у депресивних регіонах.

Необхідно також відмітити праці представників франкфуртської критичної школи, зокрема Т. Адорно та М. Хоркхаймера (Horkheimer, Adorno, 2002), які в середині XX ст. критикували концепцію культурних індустрій. За їх словами, корпорації насаджують та контролюють процес зверху, підриваючи будь-яку надію, що культура формується в середині народних мас. Аналізуючи тези проти індустріалізації культури, вчені аргументують ймовірність етнокультурної асиміляції, затирання локальних ідентичностей та їх подальшу маргіналізацію, що врешті-решт, може призвести до втрати економічного, політичного та територіального суверенітету. Однак у сучасному контексті постіндустріальних економік, креативні індустрії можуть стати потужною надбудовою матеріальнотехнічної сфери, активно залучаючи до створення доданої вартості тих, хто вивільняється з промисловості.

Нині економічна наука в Україні не приділяє значної уваги дослідженням детермінант, факторів і стратегій розвитку креативних (культурних) індустрій у національному господарстві, тоді як саме креативна економіка $є$ альтернативним джерелом створення доданої вартості, робочих місць та інструментом вирівнювання соціально-економічного розвитку регіонів. Саме тому метою статті $є$ дослідження 


\section{КРЕАТИВНІ ІНДУСТРІЇ ЯК ЕЛЕМЕНТ СТРАТЕГІЇ ПОСТІНДУСТРІАЛЬНОГО РОЗВИТКУ}

особливостей формування та визначення перспектив розвитку креативних індустрій в Україні.

Виклад основного матеріалу. Поняття креативної (культурної) індустрії, яке тісно пов'язане із концепцією креативної економіки та креативного класу, набуло активного поширення на поч. XXI ст. для позначення творчих галузей, що продукували широкий спектр товарів і послуг, забезпечували роботою велику кількість людей, використовували цифрові технології, залежали від інновацій і розвивалися, переважно, в країнах західної Європи та США. Базовою умовою формування креативної економіки стала інформаційна революція та перехід до інноваційного «суспільства знань», в якому головним необмеженим ресурсом $\epsilon$ творчий потенціал та інноваційне мислення. Нині він $є$ рушійною силою не лише для художників, музикантів, акторів тощо, але й для промисловості, бізнесу та управління. Саме креативний підхід дає можливості віднайти нові унікальні рішення в умовах турбулентного економічного середовища і жорсткої конкуренції на ринку. Вперше концепція креативних індустрій на офіційному рівні була використана в новій програмі культурної політики Австралії «Творча нація» (Creative nation..., 1994), що $€$ економічною політикою, направленою на використання нових можливостей інформаційних та цифрових технологій у сфері глобальної культури.

За визначенням ЮНКТАД (UNCTADstat) креативна економіка - це нова концепція, яка спирається на взаємодію між творчістю людини, ідеями та інтелектуальною власністю, знаннями та технологіями. До неї належать такі галузі як реклама, архітектура, декоративно-прикладне мистецтво, дизайн, мода, кіно, відео, фотографія, музика, виконавча майстерність, видавництво, дослідження та розробки, програмне забезпечення, комп'ютерні ігри, електронні видання та телебачення/радіо. Разом вони формують важливе джерело не тільки культурних, але й комерційних цінностей. Базовими для розвитку креативної економіки та культурного капіталу країни вважаються галузі культурної спадщини та виконавчих мистецтв. На рис. 1 наведено складові елементи креативних індустрій.

3 точки зору економічного змісту креативні індустрії - це економічна діяльність, заснована на використанні знань, талантів та ідей, втілених у бізнесмоделях і технологіях для отримання прибутку та реалізації творчого потенціалу. Креативні індустрії поєднують в собіпроцес створення, виробництва та комерціалізації креативного контенту, якому притаманний нематеріальний і культурний характер. Креативна економіка найменше залежить від матеріальних ресурсів, тому вона $\epsilon$ найдинамічнішою щодо створення нових робочих місць, генерування доходів та розвитку експорту.

Характерною особливістю креативних індустрій сьогодні $є$ те, що вони розвиваються переважно в містах, особливо в тих, де ринок уже насичений споживчими товарами, функціонує розвинута соціальна сфера та спостерігається 
високій рівень доходів населення. Висока якість життя та стандартів міського обслуговування підвищує економічну і соціальну динаміку, що сприяє формуванню конкурентних переваг перед ін. територіями. За даними EUROSTAT, кожен третій громадянин країн СС (35\%), який є старшим 16 років, щонайменше 1 раз на рік бере участь у культурних заходах, що позитивно впливає на якість його життя. Країнами лідерами за цим показником є Австрія, Данія, Великобританія, Франція, Литва, Латвія і Швеція - понад 50 \%. Станом на 2016 р. до креативних індустрій в ЄС було залучено 8,4 млн. осіб, або $3,7 \%$ від усіх зайнятих. Найбільша частка зайнятих в Естонії - 5,3 \%, найменша в Румунії - 1,6 \%. (EUROSTAT, 2016).

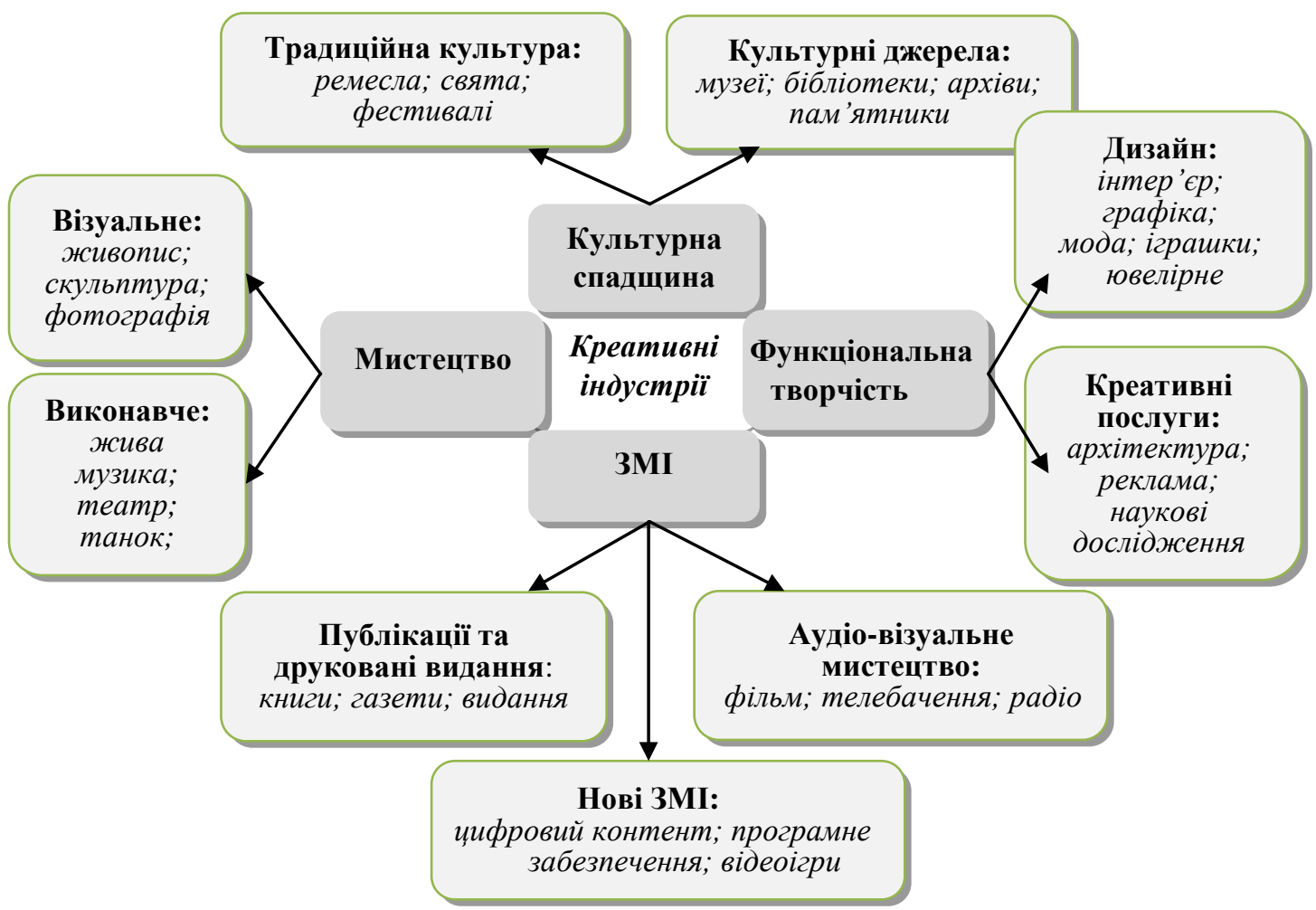

Рис. 1. Складові креативних індустрій

Джерело: сформовано на основі (Creative Economy..., 2008)

Розвиток креативних індустрій відіграє величезну роль у глобальних економічних і політичних змінах. У цілому, лідерами в креативних індустріях залишаються економічно розвинуті країни, проте доля країн, що розвиваються неухильно зростає. Якщо в 1950-ті рр. ВВП США становив понад 50 \% від світового ВВП, то нині ВВП США становить близько 25 \% світового. Це пов'язано, зокрема, і з розвитком творчих індустрій у таких країнах як Індія, Китай, Південно-Східна Азія та Латинська Америка (Loshkovska, 2014). Значний поступ у розвитку креативної економіки здійснили країни Азіатсько-Тихоокеанського регіону в яких 


\section{КРЕАТИВНІ ІНДУСТРІЇ ЯК ЕЛЕМЕНТ СТРАТЕГІЇ ПОСТІНДУСТРІАЛЬНОГО РОЗВИТКУ}

відповідний сектор генерує біля 740 млрд. дол США доходу (33 \% світового обсягу продажів креативної продукції) і представляє 12,7 млн. робочих місць (43 \% робочих місць у креативних індустріях у світовому вимірі) (Turskyi, 2016).

Однією з переваг розвитку креативних індустрій для національних економік $\epsilon$ можливість отримання прибутку від експорту, адже товари та послуги вироблені у сфері креативної економіки можуть бути об'єктами міжнародної торгівлі. На рис. 2 наведено товарообіг міжнародної торгівлі товарами, які вироблені у креативній cфepi.

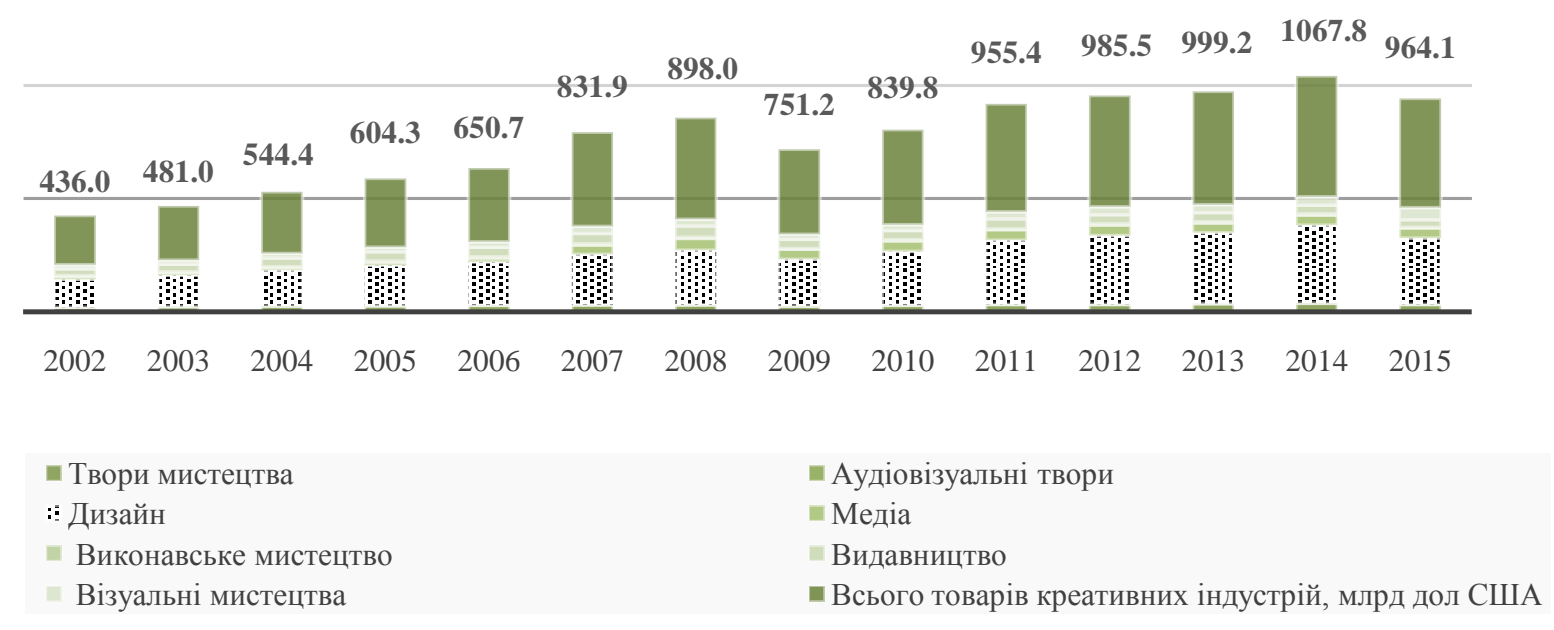

\section{Рис. 2. Товарообіг міжнародної торгівлі товарами креативної економіки, млрд. дол. США}

Джерело: Джерело: сформовано на основі (UNCTADstat, 2018)

На рис. 1 зображено, що креативні індустрії з кожним роком виробляють усе більше товарів, а міжнародна торгівля ними набирає обертів, виключенням став кризовий 2009 р. За період з 2002 по 2015 рр. загальний товарообіг зріс у 2,2 рази, а найбільшу питому вагу в його структурі займає дизайн.

Україна відповідно до рейтингу Global Creativity Index (Global Creativity Index..., 2018) за індексом креативності в 2015 р. посідала 45 місце серед 139 країн 3 показником 0,53. Даний інтегральний показник формується на основі трьох складових:

- технології (обсяг інвестицій в $\mathrm{R} \& \mathrm{D}$, обсяг патентів на душу населення та індекс технологій) - Україна зайняла 43 місце;

- талант (частка креативного класу в суспільстві, рівень освіти та індекс таланту) - 24 місце; 
- толерантність (расові та етнічні меншини, сексуальні меншини та індекс толерантності) - 105 місце. Отже, найбільшою конкурентною перевагою в Україні $\epsilon$ талант і креативний хист населення, менше розвинута толерантність.

За даними European Business Association в Україні 3-поміж 16,9 млн. економічно активного населення станом на 2016 р. до креативних індустрій залучено біля 500 тис. осіб, або $3 \%$ працюючих і генерують вони біля $5 \%$ ВВП країни. Передовою сферою креативної економіки нині $\epsilon$ IT-індустрія, яка переважно орієнтована на експорт та працює за технологією аутсорсингу, виконуючи замовлення крупних іноземних компаній. Станом на 2017 р. в Україні нараховувалося більше 130 тис. IT-спеціалістів, а обсяг експорту програмного забезпечення приніс біля 3,2 млрд. дол США. У 2017 р. до світового рейтингу The Global Outsourcing 100, увійшло 13 компаній, центри розвитку яких знаходяться в Україні. Це втричі більше, ніж у попередньому році, і в дев'ять разів більше, ніж у 2015 р. Потужним потенціалом IT-ринку $є$ технологічні та продуктові стартапи, про що свідчать великі угоди з потужними транснаціональними корпораціями (All You Need to Know ..., 2017) Зокрема, у 2012 p. Google придбали український проект Viewdle за 45 млн. дол, а в 2015 p. Snapchat купили одеський стартап Looksery за рекордну вартість - 150 млн. дол (Kak ukraintsy delayut den'gi ..., 2018). Таким чином, динамічний характер розвитку свідчить про те, що IT-індустрія в Україні може стати однією 3 передових експортоорієнтованих галузей економіки, яка генеруватиме висомаржинальний продукт та забезпечуватиме Україні сильні конкурентні позиції на світовому ринку. Для цього державі необхідно інвестувати в талант, ідеї та освіту населення, і насамперед, молодого покоління фахівців, які знаходяться на перших етапах свого професійного зростання для того, щоб формувати у спеціалістів конкретне бачення майбутніх перспектив не за межами держави, а в Україні. Крім того, необхідно зосереджувати увагу не лише на аутсорсингу, але й вибудовувати стратегії розвитку ін. сегментів ринку, таких як програмне забезпечення, комп'ютерне обладнання тощо.

Ще одним ринком креативної економіки в нашій країні з надзвичайно великим потенціалом є медійний ринок, який охоплює телебачення, онлайн ЗМІ, продакшен, рекламу, PR, радіо, кіно, друковану пресу. Орієнтований він на внутрішнього споживача, тому через тяжкі економічні умови в цілому, за оцінками фахівців European Business Association, обсяг даного ринку нині становить біля 15 млрд. грн.

Значний потенціал в Україні має і ринок «хендмейду», за різними оцінками сюди залучено від 120 до 140 тис. осіб. Поступово набирає обертів архітектурний дизайн. За підрахунками Міністерства регіонального розвитку, будівництва та житлово-комунального господарства, в Україні нараховується біля 3,7 тис. сертифікованих архітекторів. У 2016 р. за офіційними даними Державної служби статистики (Derzhavnyi komitet statystyky Ukrainy ..., 2018), в Україні було виконано 


\section{КРЕАТИВНІ ІНДУСТРІЇ ЯК ЕЛЕМЕНТ СТРАТЕГІЇ ПОСТІНДУСТРІАЛЬНОГО РОЗВИТКУ}

будівельних робіт на суму 73,7 млрд. грн, з яких на архітектуру та проектування, зазвичай, припадає біля $5 \%$. Таким чином, приблизний обсяг даного ринку може становити близько 3,7 млрд. грн. Ринки багатьох ін. секторів, які можна віднести до креативних індустрій мають ще меншу ємність. Крім того, нині відчувається недостатність інформації, зокрема і статистичних даних щодо стану креативних галузей, а це, насамперед, ускладнює аналітику та процес формування адекватної політики державної підтримки.

Для України сектор креативної економіки може стати платформою, на якій активно розвиватиметься малий і середній бізнес. У цьому ключі необхідно звернути увагу на основну проблему, з якою зустрічаються МСП - це джерела фінансування та залучення інвестицій. Окрім безпосередньої підтримки через пільгове державне кредитування, необхідно впроваджувати системну політику формування інфраструктури, підтримки проектів створення публічних креативних просторів хабів, хакспейсів, коворкінгів, антикафе та ін. Саме в таких місцях креативні й талановиті люди можуть комунікувати і презентувати свої ідеї та проекти. У регіональному аспекті важливо розвивати заклади культури, інноваційновиробничі, освітні комплекси, інформаційні технології, які прискорюватимуть залучення креативного класу до підприємницької діяльності. Важливим постає питання формування кадрового потенціалу із принципово новим розумінням культури, творчості та їх комерційної складової, що може задовольняти економічні інтереси як окремої особи, так і держави в цілому.

У світлі євроінтеграційних процесів України необхідно зауважити, що в 2015 р. ЄС запустив трирічну програму «Культура і креативність» 3 бюджетом 4,2 млн. євро, яка спрямована на підтримку і розвиток культурних індустрій в колишніх республіках СРСР (Азербайджан, Вірменія, Білорусь, Грузія, Молдова та Україна). Такі проекти створюють додаткові можливості не лише налагодження виробничих систем, але й виходу із унікальними, аутентичними продуктами української культури на міжнародні ринки.

Однією з особливостей організації креативної діяльності є залучення великої кількості жіночої праці, що забезпечує впровадження в життя політики гендерної рівності. Частка самозайнятих жінок у креативних індустріях у декілька разів перевищує аналогічний показник у цілому в економіці: зокрема, в Німеччині ці показники становлять $44 \%$ (в креативному секторі) та $7 \%$ (в цілому в економіці) відповідно (Sondermann, 2009).

Рамкова програма підтримки та розбудови креативних індустрій повинна бути результатом спільної праці двох відомств:

a) Міністерства культури, де повинні формувати нові цілі та підходи до розвитку культури в синергії 3 ін. галузями, впроваджувати сучасні умови мистецької освіти, політику брендингу культурної спадщини та дизайну привабливих територій тощо; 
б) Міністерства економічного розвитку та торгівлі України, яке повинно зосередиться на створенні сприятливих умов для стимулювання інновацій, розвитку послуг з підтримки бізнесу в сфері креативної економіки, поліпшені їх навичок і компетенцій, необхідних для участі в міжнародній торгівлі. Розвиток креативних галузей у нашій державі може стати однією 3 детермінант переходу до постіндустріального і високоінтелектуального економічного укладу. Разом iз підвищенням якості життя населення та вирівнюванням соціально-економічного розвитку регіонів з'являється можливість культурної експансії, використання величезного творчого потенціалу нації для позиціонування країни на світовому ринку.

\section{Висновки.}

1. Змістом діяльності креативних індустрій є використання знань, талантів та ідей втілених у бізнес моделях і технологіях для отримання прибутку. Вони формують найдинамічнішу економічну сферу щодо створення нових робочих місць, генерування доходів і розвитку експорту. Стрімкий характер розвитку має також і міжнародна торгівля товарами та послугами креативної економіки.

2. Найбільшою конкурентною перевагою та необмеженим ресурсом розвитку креативних індустрій в Україні $є$ талант та творчий хист населення. Значний економічний потенціал має ринок IT-технологій, медіа, «хендмейд», архітектурний дизайн та ін.

3. Для можливості реалізації своїх ключових компетенцій і забезпечення загального економічного зростання креативні індустрії потребують, по-перше, імплементації нового формату культурної політики, по-друге, впровадження комплексної програми державної підтримки, спрямованої на розвиток інфраструктури, фінансове та інформаційне забезпечення малого i середнього бізнесу.

\section{References:}

1. Culture and Creative Industries in Germany. (2009). Research Report No 577: 27. Federal Germany: Ministry of Economics and Technology.

2. 2019 annual work programme for the implementation of the Creative Europe Programme. (2018) [online], Available at:<https://ec.europa.eu/programmes/creativeeurope/sites/creative-europe/files/library/c-2018-6687.pdf> [Accessed 8 November 2018].

3. All You Need to Know about Ukrainian IT Outsourcing in 2017. (2017). [online], Available at:https://www.n-ix.com/need-know-ukrainian-it-outsourcing-2017 [Accessed 5 November 2018].

4. Collins, P., Cunningham, J. (2017). Creative Economies in Peripheral Regions. Switzerland: Springer International Publishing AG.

5. Creative nation: Commonwealth cultural policy. (1994). Australia: Department of Communications and the Arts, [online], Available at: 


\section{КРЕАТИВНІ ІНДУСТРІЇ ЯК ЕЛЕМЕНТ СТРАТЕГІЇ ПОСТІНДУСТРІАЛЬНОГО РОЗВИТКУ}

https://ru.scribd.com/document/181017857/Creative-Nation-Commonwealth-CulturalPolicy-October-1994 [Accessed 10 November 2018].

6. Derzhavnyi komitet statystyky Ukrainy [State Committee of Statistics of Ukraine], [online] Available at:<http://www.ukrstat.gov.ua/> [Accessed 2 November $2018]$.

7. EUROSTAT. (2016), [online] Available at: https://ec.europa.eu/eurostat/web/products-eurostat-news/-/DDN-20180222-

1 ? inheritRedirect $=$ true $\&$ redirect $=\% 2$ Feurostat $\% 2$ Fweb $\% 2$ Fculture $\% 2$ Fpublications [Accessed 4 November 2018].

8. Florida, R. (2002).The Rise of the Creative Class: And How It's Transforming Work, Leisure, Community and Everyday Life .New York: Basic Books.

9. Glaeser, E. (1998). 'Are Cities Dying?' Journal of Economic Perspectives, no. 12, pp. 139-160.

10. Global Creativity Index by Country. (2018). [online] Available at:http://chartsbin.com/view/41109 [Accessed 6 November 2018].

11. Horkheimer, M., Adorno, T. (2002). 'The culture industry: Enlightenment as mass deception. // In Gunzelin Schmid Noerr', [online] Available at: <https://analepsis.files.wordpress.com/2015/01/cultureindustry.pdf> [Accessed 11 November 2018].

12. Howkins, J. (2011). The Creative Economy. New York: The penguin press.

13. Jacobs, J. (1984). Cities and the Wealth of Nations. New York: Random House.

14. Kak ukraintsy delayut den'gi na ideyakh [How Ukrainians make money out of their ideas]. LigaNet, [online] Available at: <http//project.liga.net/projects/just_business/> [Accessed 2 November 2018].

15. Landry, Ch., Bianchini, F. (1995). The creative city. London: Demos.

16. Loshkovska, Kh. S. (2014). 'Kreatyvni industrii yak suchasnyi sehment stratehichnoho rozvytku krain svitu' [Creative industries as a modern segment for strategic development of countries of the world]. Aktualni problemy mizhnarodnykh vidnosyn [Topical issues of foreign affairs], no. 119, pp. 153-158.

17. Porfírio, J., Carrilho, T., Mónico L. (2018) 'Entrepreneurship in different contexts in cultural and creative industries', [online] Available at: https://www.sciencedirect.com/science/article/abs/pii/S0148296316302533?via\%3Dihub [Accessed 12 November 2018].

18. Turskyi, I. V. (2016). Hlobalni ta rehionalni trendy kreatyvnykh industrii ta perspektyvy yikh rozvytku v Ukraini [Global and regional trends of creative industries and their development prospects in Ukraine], [online] Available at:http://www.elartu.tntu.edu.ua [Accessed 5 November 2018]. 
19. UNCTADstat,

[online]

Available

at:

https://unctad.org/en/Pages/DITC/CreativeEconomy/Creative-Economy-Programme.aspx. [Accessed 14 November 2018].

(C) Карасьова Н. А.., 2019 